\title{
ANALISIS SPASIAL DAN TEMPORAL KEJADIAN DBD DI KOTA SEMARANG TAHUN 2016-2019
}

\author{
Ulfa Nor Alfiyanti, Arum Siwiendrayanti \\ Ilmu Kesehatan Masyarakat, Fakultas Ilmu Keolahragaan, \\ Universitas Negeri Semarang \\ Gedung F5 Universitas Negeri Semarang \\ e-mail: Ulfanoralfiyanti77@gmail.com
}

\begin{abstract}
Spatial and Temporal Analysis of DHF Events in Semarang City 2016-2019. The number of DHF cases in Semarang City in 2016-2019, respectively, were IR 25.27 / 100,000 population in 2016, IR 18.14 / 100,000 population in 2017, IR 6.17 / 100,000 population in 2018, and IR $26,37 / 100,000$ population in 2019. There was a very significant increase in DHF cases in 2019 after previously experiencing a decline in 2016-2018. The purpose of this study was to describe the spatiotemporal distribution of DHF incidence in Semarang City. This type of this study was descriptive. The instrument includes location maps, GIS software namely ArcGIS, and number processing software. The technique of collecting data through observation of secondary data. The research was conducted in September 2020. The data analysis technique used univariate analysis, scatterplot analysis, and spatial temporal analysis. The results of the spatiotemporal analysis showed that the larva free rate contributed to the spread of DHF incidence in Semarang City from 2016 to 2019. Meanwhile, the variables of area height and population density did not contribute.
\end{abstract}

Keywords: Spatial and temporal analysis; DHF; Semarang City

Abstrak: Analisis Spasial dan Temporal Kejadian DBD di Kota Semarang Tahun 20162019. Jumlah kasus DBD di Kota Semarang pada tahun 2016-2019 secara berurutan yaitu IR 25,27 / 100.000 penduduk pada tahun 2016, IR 18,14 / 100.000 penduduk pada tahun 2017, IR 6,17 / 100.000 penduduk pada tahun 2018, dan IR 26,37 / 100.000 penduduk pada tahun 2019. Terjadi kenaikan Kasus DBD yang sangat signifikan pada tahun 2019 setelah sebelumnya mengalami penurunan pada tahun 2016-2018. Tujuan penelitian ini adalah untuk mengetahui gambaran distribusi spasiotemporal kejadian DBD di Kota Semarang. Jenis penelitian ini adalah deskriptif. Instrument meliputi peta lokasi, perangkat lunak GIS yaitu ArcGIS, dan perangkat lunak pengolah angka. Teknik pengambilan data melalui observasi data sekunder. Penelitian dilaksanakan bulan September 2020. Teknik analisa data menggunakan analisis univariat, analisis scatterplot, dan analisis spasial temporal. Hasil analisis spasiotemporal menunjukkan bahwa angka bebas jentik berkontribusi terhadap persebaran kejadian DBD di Kota Semarang tahun 2016 - 2019. Sedangkan variabel ketinggian wilayah dan kepadatan penduduk tidak berkontribusi.

Kata kunci: Analisis Spasial dan temporal; DBD; Kota Semarang

\section{PENDAHULUAN}

Pada tahun 2018 kasus DBD di Indonesia berjumlah 65.602 kasus, dengan jumlah kematian sebanyak 467 orang [1]. Di Jawa Tengah, penyakit DBD masih menjadi permasalahan yang serius, yang dibuktikan oleh 35 kabupaten/kota di Jawa Tengah yang sudah terjangkit DBD[2]. Demikian pula dengan beberapa wilayah di Jawa Tengah, DBD menjadi permasalahan serius termasuk diantara- nya adalah Kota Semarang [2]. Dinas Kesehatan Kota Semarang mencatat terjadi kenaikan Kasus DBD yang sangat signifikan pada tahun 2019 setelah sebelumnya mengalami penurunan pada tahun 2016-2018. Oleh karena itu, hal ini menjadi permasalahan serius yang perlu diperhatikan. Kecamatan Tembalang merupakan salah satu wilayah endemis penyakit DBD di Kota Semarang yang menempati urutan pertama kasus DBD 
tertinggi di Kota Semarang pada tahun 2019 dengan IR 68,22/100.000 penduduk. Sedangkan kasus DBD terendah di Kota Semarang pada tahun 2019 ditempati oleh Kecamatan Tugu dengan IR 8,96/100.000 penduduk (Dinkes Kota Semarang, 2019).

Peningkatan dan persebaran kasus DBD dapat dipengaruhi oleh host, agent, dan environtment yang terdiri dari aspek demografi (kepadatan penduduk, mobilitas penduduk, perilaku dan sosial ekonomi pennduduk), dan aspek geografi[3]. Pada aspek lingkungan geografi, ketinggian wilayah merupakan faktor penting untuk membatasi penyebaran nyamuk. Pengaruh variasi ketinggian wilayah dapat berpengaruh terhadap syarat-syarat ekologis yang diperlukan oleh vektor penyakit. Ketinggian 1000 - 1500 mdpl merupakan batas bagi penyebaran nyamuk Aedes Aegypti[4]. Virus dengue penyebab Demam Berdarah Dengue akan bereplikasi didalam tubuh manusia setelah digigit oleh nyamuk Aedes, sehingga akan semakin banyak virus dengue yang terinkubasi ke manusia, dengan demikian akan semakin banyak pula manusia yang akan menjadi penular. Semakin padat penduduk maka perkembangan virus akan semakin kondusif sehingga kasus DBD dimasyarakat semakin banyak ${ }^{[5]}$.

ABJ (Angka Bebas Jentik) menjadi indikator keberhasilan kegiatan PSN (Pemberantasan Sarang Nyamuk) dan pencegahan awal demam berdarah dengan memastikan rumah negatif dengan larva Aedes Aegypty. Selama masih terdapat tempat peridukan, nyamuk dapat dengan leluasa berkembang biak dan menghasilkan nyamuk baru. Apabila nyamuk yang baru menetas terinfeksi virus Dengue maka penularan penyakit DBD akan terjadi kembali[6]. Penelitian ini bertujuan untuk mengetahui gambaran distribusi spasiotemporal kejadian DBD di Kota Semarang tahun 2016 - 2019.

\section{BAHAN DAN CARA PENELITIAN}

Jenis penelitian ini adalah deskriptif. Penelitian ini dilakukan pada bulan September 2020. Dalam penelitian ini digunakan data sekunder yang diperoleh dari instansi terkait, yaitu Dinas Kesehatan Kota Semarang dan Badan Pusat Statisik Kota Semarang. Data kasus DBD dan ABJ diperoleh dari DKK Semarang. Sedangkan data ketinggian wilayah dan kepadatan penduduk diperolehh dari BPS Kota Semarang. Instrument yang digunakan dalam penelitian ini adalah, peta lokasi, perangkat lunak GIS yaitu ArcGIS, dan perangkat lunak pengolah angka untuk mengola data sekunder. Teknik pengambilan data dalam penelitian ini adalah melalui observasi data sekunder yang meliputi data kejadian DBD, data ketinggian wilayah, data kepadatan penduduk, dan data angka bebas jentik yang diperoleh dari instansi terkait. Teknik analisa data menggunakan analisis univariat, analisis scatterplot, dan analisis spasial temporal.

\section{HASIL PENELITIAN DAN PEMBAHASAN}

Data kepadatan penduduk di Kota Semarang diperoleh dari Badan Pusat Statistika Kota Semarang. Kepadatan penduduk di Kota Semarang mengalami kenaikan di setiap tahunnya. Pada tahun 2016 kepadatan penduduk di Kota Semarang berjumlah 4.289 jiwa/ $\mathrm{Km}^{2}$ dan terus mengalami kenaikan hhingga pada tahun 2019 kepadatan penduduk di Kota Semarang menempati angka 4.855 jiwa $\mathrm{Km}^{2}$.

Kepadatan penduduk di Kota Semarang sangat bervariasi di setiap kecamatannya. Kecamatan Semarang Selatan adalah kecamatan dengan kepadatan penduduk tertinggi pada tahun 2016. Kecamatan Gayamsari merupakan kecamatan dengan kepadatan penduduk tertinggi disepanjang tahun 2017 sampai dengan 2019. Sedangkan kecamatan dengan kepadatan penduduk terendah ditempati oleh Kecamatan Tugu selama berturut-turut pada tahun 2016 sampai dengan tahun 2019. 
Tabel 1. Data Kepadatan Penduduk 16 Kecamatan di Kota Semarang Tahun 2016-2019

\begin{tabular}{lcccc}
\hline \multicolumn{1}{c}{ Kecamatan } & \multicolumn{4}{c}{ Kepadatan Penduduk } \\
\multicolumn{1}{c}{$(1)$} & 2016 & 2017 & 2018 & 2019 \\
& $(2)$ & $(3)$ & $(4)$ & $(6)$ \\
\hline Banyumanik & 5.196 & 6.072 & 6.322 & 6.421 \\
Candisari & 12.059 & 11.613 & 11.570 & 11.752 \\
Gajahmungkur & 7.030 & 6.611 & 6.587 & 6.690 \\
Gayamsari & 12.000 & 12.853 & 13.235 & 13.443 \\
Genuk & 3.633 & 4.045 & 4.278 & 4.345 \\
Gunungpati & 1.478 & 2.023 & 2.161 & 2.195 \\
Mijen & 1.101 & 1.213 & 1.301 & 1.321 \\
Ngaliyan & 3.336 & 4.050 & 4.281 & 448 \\
Pedurungan & 8.766 & 9.839 & 10.202 & 10.361 \\
Semarang Barat & 7.247 & 7.408 & 7.475 & 7.592 \\
Semarang Selatan & $13 . .354$ & 11.755 & 11.713 & 11.896 \\
Semarang Tengah & 11.353 & 9.833 & 9.798 & 9.951 \\
Semarang Timur & 9.949 & 9.722 & 9.687 & 9.839 \\
Semarang Utara & 11.589 & 10.771 & 10.738 & 10.907 \\
Tembalang & 3.599 & 4.394 & 4.667 & 4.740 \\
Tugu & 1.008 & 1.008 & 1.033 & 1.049 \\
\hline
\end{tabular}

Sumber: BPS Kota Semarang Tahun 2016-2019

Observasi data rata-rata ketinggian wilayah setiap kecamatan di Kota Semarang diperoleh dari Badan Pusat
Statistika Kota Semarang. Berikut merupakan data rata-rata ketinggian wilayah setiap kecamatan di Kota Semarang:

Tabel 2. Rata-rata Ketinggian Wilayah Kecamatan di Kota Semarang

\begin{tabular}{lc}
\hline \multicolumn{1}{c}{ Kecamatan } & Ketinggian Wilayah (mdpl) \\
\hline Banyumanik & 300,0 \\
Candisari & 2,5 \\
Gajahmungkur & 150,0 \\
Gayamsari & 3,5 \\
Genuk & 2,0 \\
Gunungpati & 300,0 \\
Mijen & 311,0 \\
Ngaliyan & 11,0 \\
Pedurungan & 6,0 \\
Semarang Barat & 3,0 \\
Semarang Selatan & 6,0 \\
Semarang Tengah & 2,0 \\
Semarang Timur & 2,0 \\
Semarang Utara & 1,0 \\
Tembalang & 125,0 \\
Tugu & 1,0 \\
\hline Sumber: BPS Kota Semarang Tahun 2016-2019
\end{tabular}

Observasi data angka bebas jentik diperoleh dari Dinas Kesehatan Kota Semarang. Data tersebut merupakan hasil laporan dari puskesmas di masing-masing kecamatan di Kota Semarang. Data angka 
bebas jentik tersebut adalah sebagai berikut:

Tabel 3. Data Angka Bebas Jentik 16 Kecamatan di Kota Semarang

\begin{tabular}{lcccc}
\hline \multirow{2}{*}{\begin{tabular}{c} 
Kecamatan \\
\multicolumn{1}{c}{$(1)$}
\end{tabular}} & $\begin{array}{c}c \\
\text { Angka Bebas Jentik \% }\end{array}$ \\
\cline { 2 - 5 } & 2016 & 2017 & 2018 & 2019 \\
$(2)$ & $(3)$ & $(4)$ & $(5)$ \\
\hline Banyumanik & 91,39 & 92,78 & 96,21 & 90,63 \\
Candisari & 72,97 & 88,76 & 93,94 & 87,4 \\
Gajah Mungkur & 88,76 & 88,82 & 94,48 & 91,92 \\
Gayamsari & 72,97 & 93,36 & 94,11 & 95,02 \\
Genuk & 88,82 & 93,00 & 95,93 & 93,60 \\
Gunungpati & 93,03 & 93,01 & 96,14 & 92,10 \\
Mijen & 97,12 & 96,82 & 97,50 & 95,37 \\
Ngalian & 91,95 & 95,28 & 96,83 & 95,04 \\
Pedurungan & 94,13 & 96,52 & 98,35 & 95,91 \\
Semarang Barat & 54,83 & 89,42 & 93,35 & 91,53 \\
Semarang Selatan & 88,63 & 88,63 & 94,99 & 88,72 \\
Semarang Tengah & 91,11 & 89,27 & 93,27 & 92,57 \\
Semarang Timur & 83,33 & 88,01 & 92,59 & 89,32 \\
Semarang Utara & 93 & 85,41 & 95,11 & 91,93 \\
Tembalang & 91,37 & 93,35 & 97,77 & 93,81 \\
Tugu & 90 & 93,27 & 94,66 & 93,84 \\
\hline Sumber : Dinas Kesehatan Kota Semarang $2016-2019$
\end{tabular}
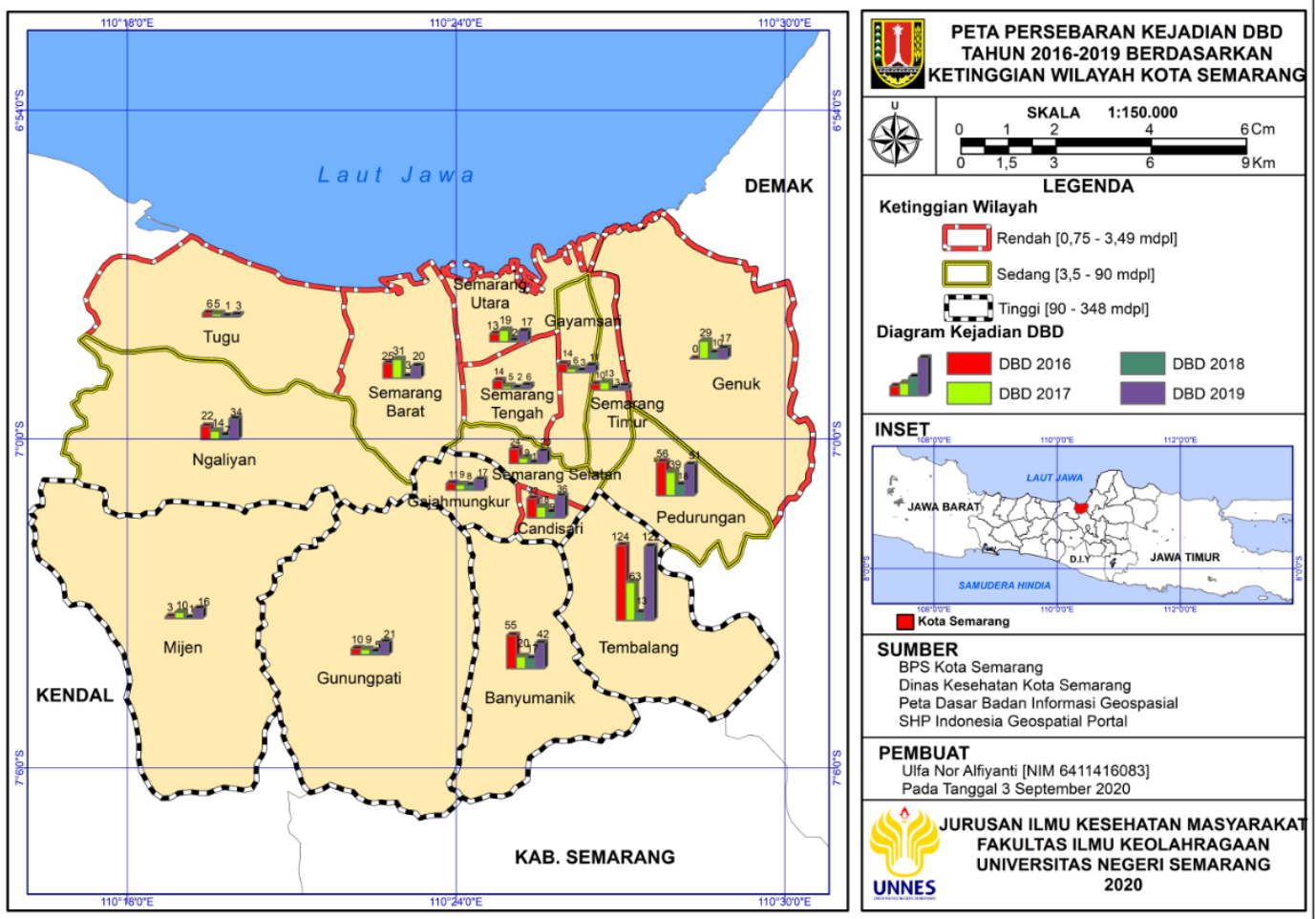

Gambar 1. Peta overlay persebaran kejadian DBD tahun 2016 - 2019 berdasarkan ketinggian wilayah 


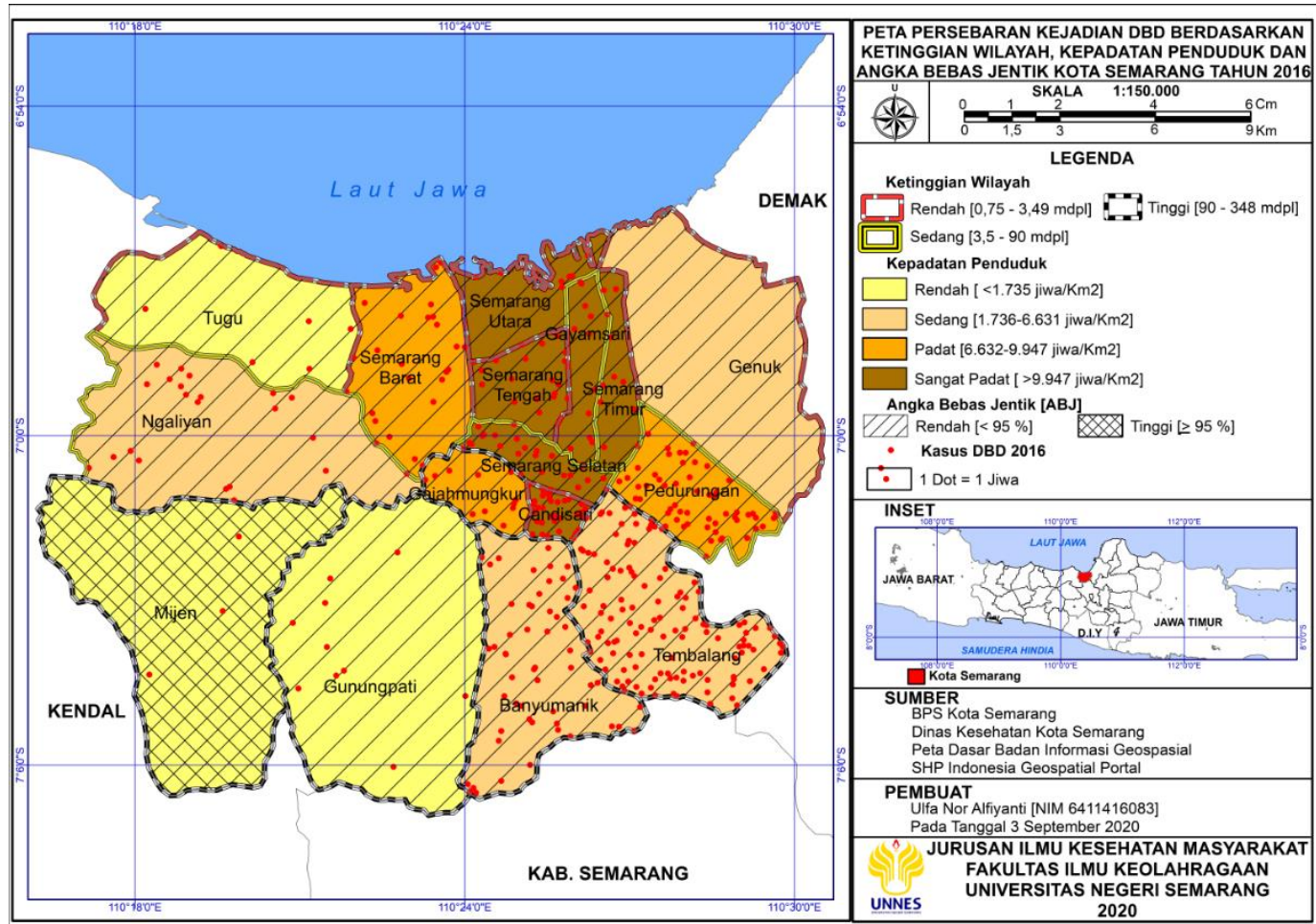

Gambar 2 Peta overlay persebaran kejadian DBD di Kota Semarang tahun 2016
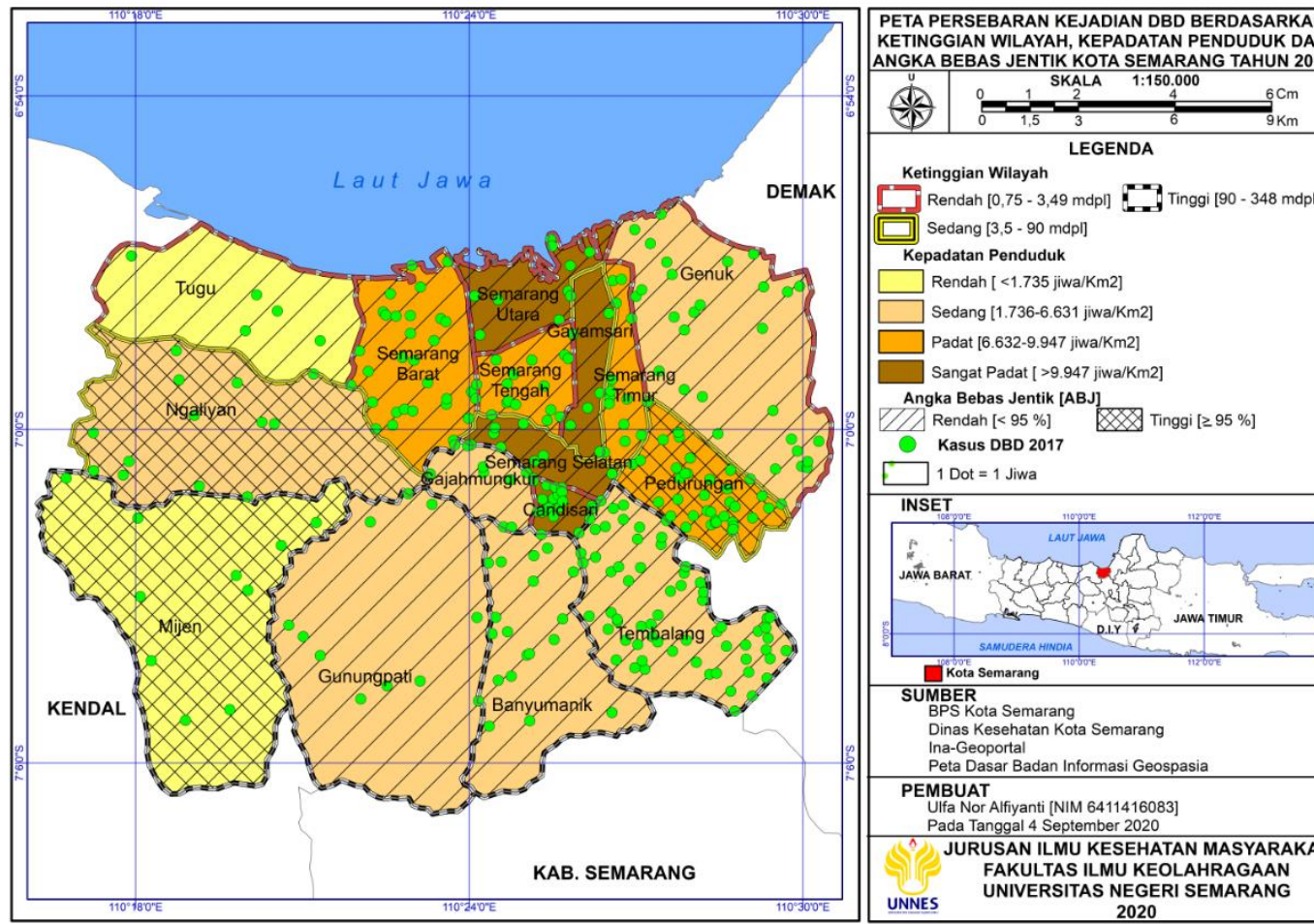

Ketinggian Wilayah

Rendah $[0,75-3,49 \mathrm{mdpl}]$ Tinggi $[90-348 \mathrm{mdpl}$

$\square$ Sedang [3,5 - $90 \mathrm{mdpl}]$

Kepadatan Penduduk

Rendah $[<1.735$ jiwa/Km2]

Sedang [1.736-6.631 jiwa/Km2]

Padat [6.632-9.947 jiwa/Km2]

Sangat Padat [ $>9.947$ jiwa/Km2]

Angka Bebas Jentik [ABJ]
Rendah [<95\%] Tinggi [ $295 \%]$

Kasus DBD 2017

1 Dot $=1$ Jiwa

INSET

$\square$ Kota Semarang

SUMBER

BPS Kota Semarang

Dinas Kesehatan Kota Semarang

Ina-Geoportal
Peta Dasar Badan Informasi Geospasia

PEMBUAT

Ulfa Nor Alfiyanti [NIM 6411416083]

JURUSAN ILMU KESEHATAN MASYARAKA

FAKULTAS ILMU KEOLAHRAGAAN FAKULTAS ILMU KEOLAHRAGAAN
UNIVERSITAS NEGERI SEMARANG

UNNES UNIVERSITAS NEGE

Gambar 3 Peta overlay persebaran kejadian DBD di Kota Semarang tahun 2017 

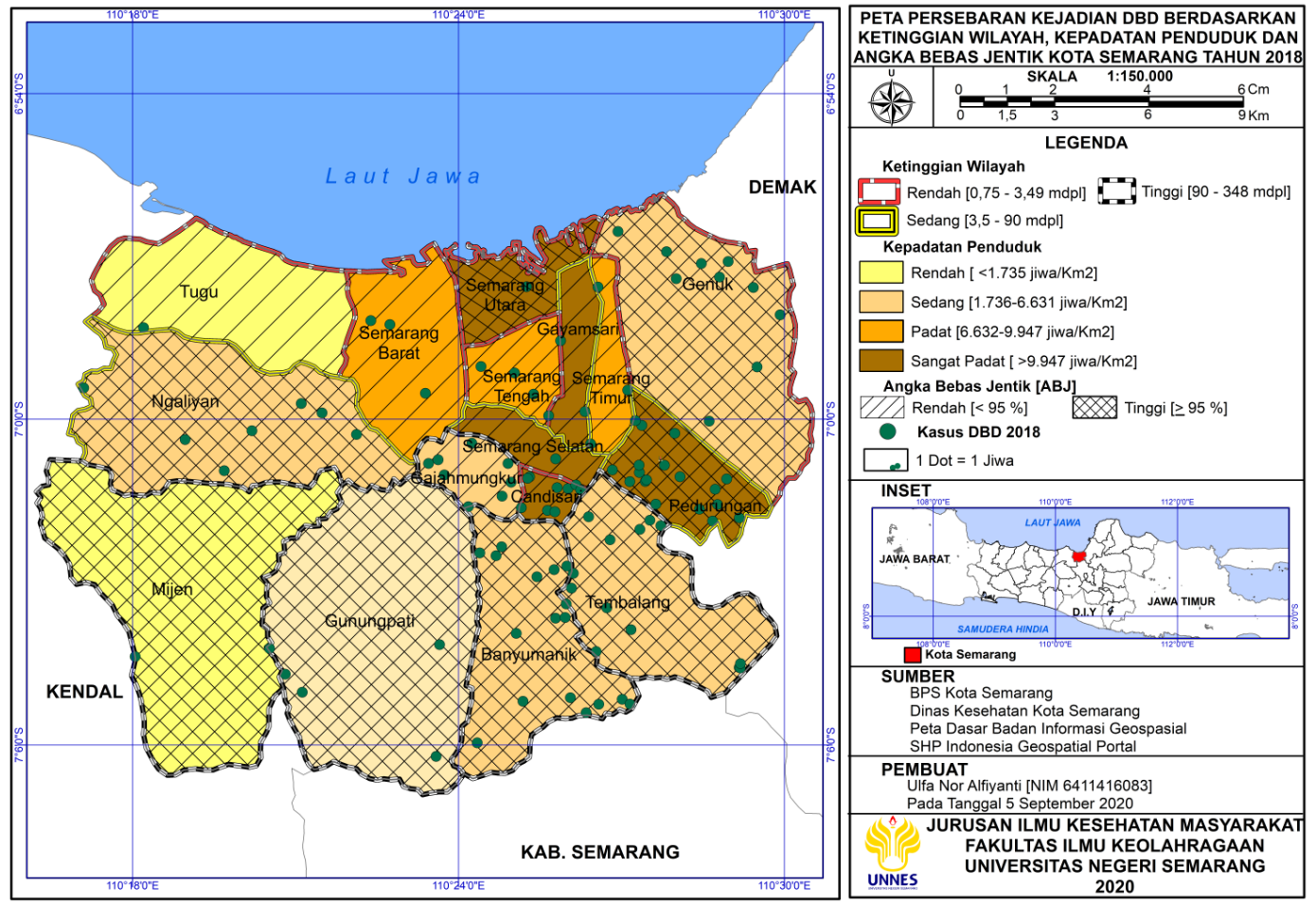

Gambar 4 Peta overlay persebaran kejadian DBD di Kota Semarang tahun 2018
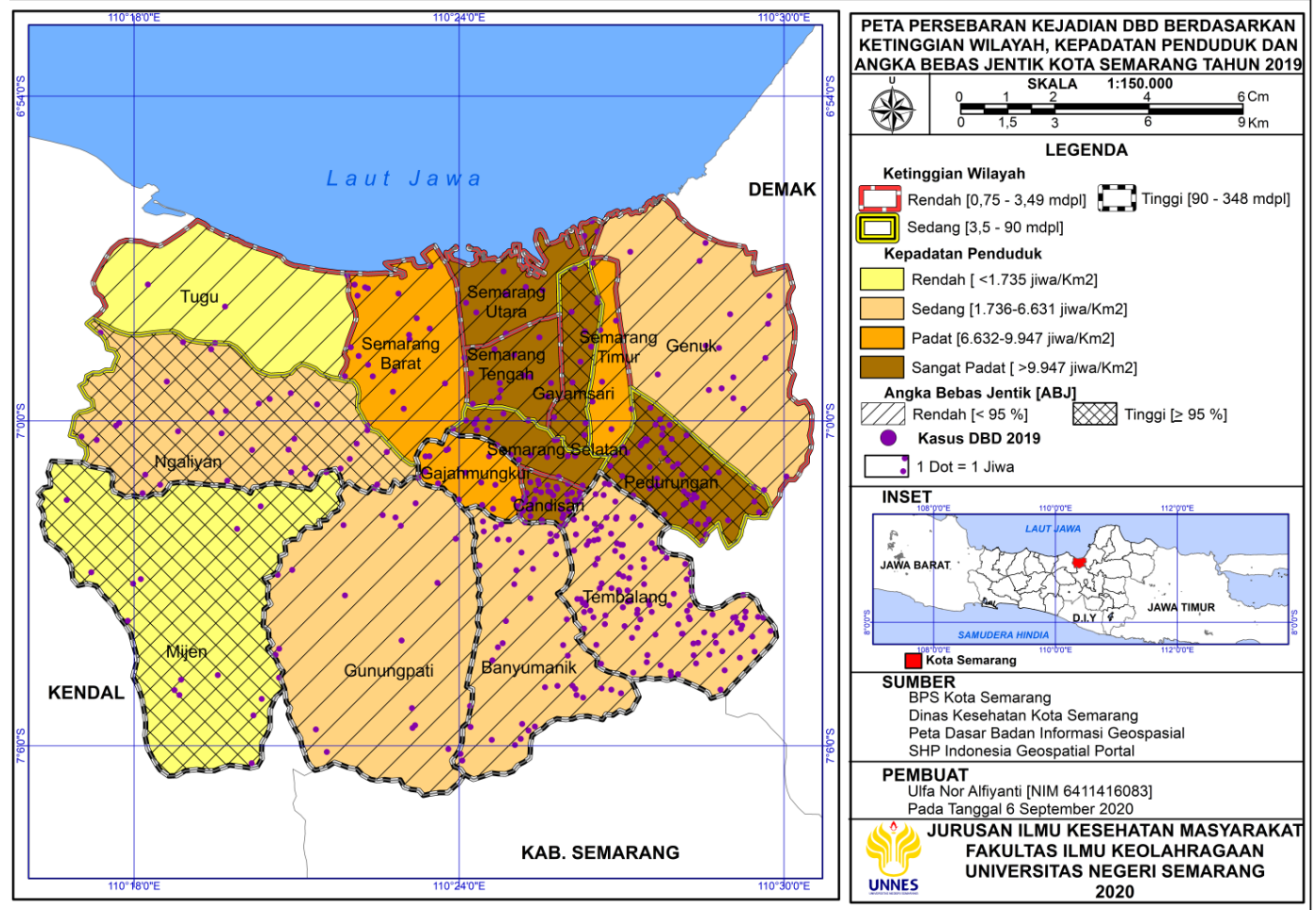

Gambar 5 Peta overlay persebaran kejadian DBD di Kota Semarang tahun 2019 
Gambar 1 sampai dengan Gambar 5 merupakan tampilan peta overlay persebaran kejadiann DBD berdasarkan ketinggian wilayah, kepadatan penduduk, dan angka bebas jentik. masing-masing variabel dalam analisis spasial dilakukan pengkategorian. Pengkategorian didapatkan dari beberapa referensi penelitian terdahulu dan peraturan pada instansi terkait. Dalam penelitian ini terdapat satu variabel yang nilainya tidak pernah berubah setiap tahunnya, yaitu variabel ketinggian wilayah. Oleh karena itu, untuk mempermudah dalam menganalisis digunakan satu peta overlay antara ketinggian wilayah dan kejadian Demam Berdarah Dengue tahun 2016 - 2019 yang ditampilkan dalam Gambar 1.

Paomey dkk mengemukakan dalam studinya bahwa sebaran kasus DBD lebih banyak terdapat pada dataran dengan ketinggian rendah dan pada daerah dengan kepadatan penduduk tinggi[7]. Penelitian Febriyanto menunjukkan bahwa terjadi pengelompokan kasus DBD di wilayah dengan kepadatan penduduk tinggi [8]. Dalam studinya, Agcrista dkk menunjukkan bahwa terdapat pola persebaran kejadian DBD yang berkerumun (clustered) pada wilayah yang memiliki nilai ABJ (Angka Bebas Jentik) yang rendah dan sebaliknya pada wilayah dengan ABJ (Angka Bebas Jentik) yang tinggi didapatkan persebaran kasus DBD dengan pola tidak berkerumun [9]. Namun, pada penelitian ini memberikan hasil bahwa ketinggian wilayah dan kepadatan penduduk tidak berkontribusi terhadap persebaran kasus DBD. Terdapat banyak kemungkinan yang dapat terjadi. Penelitian menggunakan rata-rata kepadatan penduduk dan ketinggian wilayah kecamatan, sehingga tidak bisa menggambarkan kepadatan penduduk dan ketinggian wilayah di rumah penderita.

Berdasarkan hasil analisis spasial yang telah dilakukan, dapat dilihat bahwa ketinggian wilayah sedang hingga tinggi persebaran kasus DBD cenderung mengalami penurunan. Kecamatan tersebut adalah Kecamatan Ngaliyan, Semarang Selatan, Gayamsari, Pedurungan, Gunungpati, Banyumanik, Tembalang, Gajahmungkur. Sedangkan kasus DBD di Kecamatan Mijen cenderung fluktuatif. Pada ketinggian wilayah rendah terdapat 3 kecamatan yang tren kasusnya cenderung menurun, yaitu Kecamatan Tugu, Candisari, dan Semarang Tengah. Sedangkan 4 kecamatan lainnya yaitu Kecamatan Semarang Barat, Semarang Utara, Semarang Timur, dan Genuk tren kasusnya cenderung fluktuatif. Apabila dilihat dari persebaran kasusnya, wilayah dengan kasus DBD tertinggi pada tahun 2016, 2017, 2019 adalah Kecamatan Tembalang yang memiliki ketinggian wilayah dengan kategori tinggi. Dan wilayah dengan kasus DBD tertinggi pada tahun 2018 adalah Kecamatan Pedurungan yang memiliki ketinggian wilayah dengan kategori sedang. Sedangkan wilayah dengan kasus DBD terendah pada tahun 2016 -2019 Kecamatan Tugu dan Semarang Tengah yang memiliki ketinggian wilayah dengan kategori rendah, Mijen yang memiliki ketinggian wilayah dengan kategori tinggi, dan Semarang Selatan yang memiliki ketinggian wilayah dengan kategori sedang. Sehingga dapat dikatakan bahwa ketinggian wilayah tidak berkontribusi terhadap persebaran kasus DBD di Kota Semarang dalam kurun waktu 4 tahun terakhir (2016-2019). Sama halnya dengan hasil penelitian yang dilakukan oleh Sucipto dkk yang menyatakan bahwa ketinggian tempat tidak signifikan dengan kejadian DBD [10].

Berdasarkan hasil analisis spasial, terdapat 3 kecamatan dengan persebaran kasus DBD tertinggi pada tahun 20162019 adalah kecamatan Tembalang, Pedurungan, Banyumanik. Dari 3 kecamatan tersebut, Kecamatan Tembalang dan Kecamatan Banyumanik memiliki kepadatan penduduk dengan kategori sedang pada tahun 2016-2019. Sedangkan Kecamatan Pedurungan memiliki kepadatan penduduk dengan kategori padat pada tahun 2016-2017 dan kategori sangat padat pada tahun 2018-2019. Sedangkan 
3 kecamatan dengan perseba-ran kasus DBD terendah tahun 2016 adalah Kecamatan Genuk dengan kepadatan penduduk kategori sedang, Kecamatan Mijen dengan kepadatan penduduk kategori rendah, dan Kecamatan Tugu dengan kepadatan penduduk kategori rendah. Tiga kecamatan dengan persebaran kasus DBD terendah tahun 2017 adalah Kecamatan Tugu dengan kepadatan penduduk kategori rendah, Kecamatan Semarang Tengah dengan kepadatan penduduk kategori padat, Kecamatan Gayamsari dengan kepadatan penduduk kategori sangat padat. Tiga Kecamatan dengan persebaran kasus DBD terendah tahun 2018 adalah Kecamatan Tugu dengan kepadatan penduduk kategori rendah, Kecamatan Mijen dengan kepadatan penduduk kategori rendah, dan Kecamatan Semarang Selatan dengan kepadatan penduduk kategori sangat padat. Tiga Kecamatan dengan persebaran kasus DBD terendah tahun 2019 adalah Kecamatan Tugu dengan kepadatan penduduk kategori rendah, Kecamatan Semarang tengah dengan kepadatan penduduk kategori sangat padat, dan Kecamatan Semarang Timur dengan kepadatan penduduk kategori padat. Apabila dilihat dari tren kasus DBD, kepadatan penduduk berkontribusi terhadap persebaran kasus DBD di 6 kecamatan. Apabila kepadatan penduduk menurun, maka kasus DBD juga ikut menurun begitupun sebaliknya. Kecamatan tersebut adalah Kecamatan Semarang Tengah, Kecamatan Semarang Selatan, Kecamatan Ngaliyan, Kecamatan Gajahmungkur, Kecamatan Pedurungan, dan Kecamatan Gayamsari. Sedangkan kepadatan penduduk tidak berkontribusi terhadap persebaran kasus DBD di 10 kecamatan lain yaitu Kecamatan Banyumanik, Candisari, Genuk, Gunungpati, Mijen, Tugu, Semarang Barat, Semarang Timur, Semarang Utara, dan Tembalang. Sehingga dapat dikatakan bahwa kepadatan penduduk tidak berkontribusi terhadap persebaran kasus DBD di Kota Semarang dalam kurun waktu 4 tahun terakhir (2016-2019). Sama halnya dengan hasil penelitian yang dilakukan oleh Febriyanto bahwa tidak terjadi kecenderungan peningkatan dan pengelompokan kassus DBD di daerah dengan kepadatan penduduk tinggi [8]. Berdasarkan hasil tersebut, dapat dicermati bahwa system pencatatan data penderita DBD berkontribusi terhadap tingginya kasus DBD disuatu wilayah. Dengan ditemukannya angka kasus DBD yang tinggi disuatu wilayah memungkinkan dapat mencerminkan sistem pencatatan data penderita DBD yang baik. Faktor lain yang memungkinkan ikut berkontribusi adalah pencatatan penduduk hanya dilakukan pada penduduk asli yang menetap di suatu wilayah tersebut. Sehingga terdapat penduduk pendatang yang tidak terdata, misalkan mahasiswa yang kost di wilayah tersebut. Selain itu, kondisi pemukiman dan perilaku masyarakat di wilayah tersebut juga dapat berkontribusi terhadap tingginya kasus DBD. Kondisi pemukiman yang kumuh, cara penanganan sampah dan pembuangan air limbah rumah tangga yang salah, kebiasaan tidak menguras bak mandi, kebiasaan menggantung pakaian, dan tidak melakukan kegiatan 3M menjadikan nyamuk memiliki lebih banyak tempat untuk bertelur dan bertahan hidup. Sehingga, bukan masalah apabila kepadatan penduduk tinggi diimbangi dengan kondisi pemukiman yang bersih dan perilaku masyarakat yang baik, tentunya kasus DBD akan dapat dikendalikan.

Berdasarkan analisis spasial yang telah dilakukan, kecamatan dengan persebaran kasus DBD tertinggi tahun 2016-2017 adalah Kecamatan Tembalang yang memiliki presentase angka bebas jentik rendah. Sedangkan pada tahun 2018 kecamatan dengan persebaran kasus DBD tertinggi adalah Kecamatan Pedurungan yang memiliki presentase angka bebas jentik yang tinggi. Kecamatan dengan persebaran kasus DBD tertinggi tahun 2019 adalah Kecamatan Tembalang dengan presentase angka bebas jentik yang rendah. Apabila dilihat dari tren kasus DBD, terdapat 14 kecamatan yang 
menunjukkan keterkaitan antara presentase angka bebas jentik dengan kasus DBD. Apabila presentase angka bebas jentik meningkat, maka kasus DBD akan menurun. Begitupun sebaliknya, apabila angka bebas jentik menurun, maka kasus DBD akan meningkat. Kecamatan tersebut adalah Kecamatan Tugu, Semarang Utara, Genuk, Candisari, Gayamsari, Pedurungan, Semarang Selatan, Semarang Timur, Ngaliyan, Tembalang, Gajahmungkur, Banyumanik, Mijen, dan Gunungpati. Sedangkan 2 kecamatan lainnya tidak menunjukkan adanya keterkaitan antara kedua variabel tersebut adalah Kecamatan Semarang Barat dan Kecamatan Semarang Utara. Angka bebas jentik menjadi parameter keberhasilan dari kegiatan pemantauan jentik secara rutin dan berkelanjutan. Kegiatan ini diikuti juga dengan $3 \mathrm{M}$ plus untuk memberantas sarang nyamuk dan mengurangi keberadaan jentik, sehingga nyamuk tidak memiliki tempat lagi untuk bertelur dan tumbuh dewasa. Oleh karena itu, angka bebas jentik berkaitan dengan populasi nyamuk Aedes Aegypti vektor utama DBD. Adanya keterkaitan antara kasus DBD dan presentase angka bebas jentik tersebut sejalan dengan pernyataan Kusuma dan Sukendra dalam penelitiannya yang menyatakan bahwa semakin tinggi angka bebas jentik pada suatu wilayah maka semakin rendah kasus DBD yang terjadi begitu juga sebaliknya [9]. Selain itu, juga selaras dengan penelitian yang dilakukan oleh Shinta Anggraini yang menunjukkan bahwa terdapat hubungan antara keberadaan jentik dengan kejadian DBD[11].

\section{KESIMPULAN DAN SARAN}

Simpulan dari penelitian ini adalah ketinggian wilayah dan kepadatan penduduk tidak berkontribusi terhadap persebaran kasus DBD di Kota Semarang tahun 2016-2019. Sedangkan angka bebas jentik berkontribusi terhadap persebaran kasus DBD di 14 kecamatan di Kota Semarang tahun 2016-2019.

\section{UCAPAN TERIMA KASIH}

Terimakasih penulis ucapkan kepada Dinas Kesehatan Kota Semarang dan Badan Pusat Statistik Kota Semarang atas data-data yang telah diberikan dalam penulisan artikel ini.

\section{KEPUSTAKAAN}

1. Kemenkes RI. (2018). profil kesehatan Indonesia.

2. Dinkes Prov. Jateng. (2018). Profil Jawatengah.

3. Ariati, J., \& Anwar, A. (2014). Model Prediksi Kejadian Demam Berdarah Dengue (DBD) Berdasarkan Faktor Iklim di Kota Bogor,Jawa Barat. Buletin Penelitian Kesehatan.

4. Lukmanjaya, G., Martini, \& Hestiningsih, R. (2012). Kepadatan Aedes spp Berdasarkan Ketinggian Tempat di Kabupaten Wonosobo. Jurnal Kesehatan Masyarakat.

5. Sintorini, M. M. (2007). Pengaruh Iklim terhadap Kaus Demam Berdarah Dengue. Jurnal Kesehatan Masyarakat Nasional, 2.

6. Chandra, E. (2019). Pengaruh Faktor Iklim, Kepadatan Penduduk dan Angka Bebas Jentik (ABJ) Terhadap Kejadian Demam Berdarah Dengue (DBD) di Kota Jambi. Jurnal Pembangunan Berkelanjutan, 1.

7. Paomey, V. C., Nelwan, J. E., \& Kaunang, W. P. (2019). Sebaran Penyakit Demam Berdarah Dengue Berdasarkan Ketinggian dan Kepadatan Penduduk di Kecamatan Malalayyang Kota Manado Tahun 2019. Jurnal Kesmas.

8. Febriyanto, M. R. (2012). Analisis Spasiotemporal Kasus Demam Berdarah Dengue di Kecamatan Ngaliyan Bulan Januari-Mei 201. Semarang: Universitas Diponegoro.

9. Anggrainni, S. (2018). Hubungan Keberadaan Jentik Dengan Kejadian DBD Di Kelurahan Kedurus Surabaya. Jurnal Kesehatan Lingkungan.

10. Sucipto, P. T., Raharjo, M., \& Nurjazuli. (2015). Faktor-Faktor Yang Mempengaruhi Kejadian Penyakit Demam Berdarah Dengue (DBD) Dan 
Jenis Serotipe Virus Dengue Di Kabupaten Semarang. Jurna Kesehatan Lingkungan Indonesia.
11. Anggrainni, S. (2018). Hubungan Keberadaan Jentik Dengan Kejadian DBD Di Kelurahan Kedurus Surabaya. Jurnal Kesehatan Lingkungan. 